\title{
Vergelyking van die uitwerking van sedentêre en aktiewe werkomgewings op algehele welstand
}

\begin{abstract}
Authors:
Lee-Anne Naicker ${ }^{1}$

Peet Du Toit ${ }^{1}$

Evangeline Nortje ${ }^{1}$

Michael Kleynhans ${ }^{1}$

Ronél Ferreira ${ }^{2}$

Gerda Gericke ${ }^{3}$

\section{Affiliations:}

${ }^{1}$ Department of Human Physiology, School of

Medicine, Faculty of Health Sciences, Associate of the Institute for Food, Nutrition and Well-being, Associate of the Institute for Cellular and Molecular Medicine, University of Pretoria,

South Africa

${ }^{2}$ Department of Educationa Psychology, Associate of the Institute for Food, Nutrition and Well-being, University of Pretoria, South Africa
\end{abstract}

${ }^{3}$ Department of Human Nutrition, Associate of the Institute for Food, Nutrition and Well-being, University of Pretoria, South Africa

\section{Correspondence to:}

Peet Du Toit

Email:

peet.dutoit@up.ac.za

\section{Postal address:}

PO Box 15875, Sinoville 0129

South Africa

Dates:

Received: 19 Aug. 2013

Accepted: 11 Sept. 2013

Published: 28 Oct. 2013

How to cite this article: Naicker, L-A., Du Toit, P. Nortje, E., Kleynhans, M., Ferreira, R. \& Gericke, G., 2013, Vergelyking van die uitwerking van sedentêre en aktiewe werkomgewings op algehele welstand', Suid-Afrikaanse Tydksrif vir Natuurwetenskap en Tegnologie 32(1), Art \#768, 6 pages. http://dx.doi.org/ $10.4102 /$ satnt.v32i1.768

\section{Read online:}

Die begrip welstand het oor die afgelope dekades verander na gelang die lewenstyl van die samelewing met tegnologiese vooruitgang tred gehou het. Die hedendaagse siening is dat welstand in die eerste plek die verantwoordelikheid van die individu self is en bepaal word deur die beoefening van gedrag wat gesondheid bevorder. Daar is verskeie faktore wat bydra tot gesondheid in die sin van ' $n$ individu se gevoel van algehele welstand op die lang termyn. Een van die belangrikstes daarvan is fisieke aktiwiteit, en daar is aansienlike navorsing gedoen om die voordele van 'n fisiek aktiewe lewenstyl te ondersoek. Hierdie navorsingsoorsig gaan van die veronderstelling uit dat die mees akkurate metode om dié voordele te peil, is om 'n aktiewe met 'n sedentêre lewenstyl te vergelyk. Die doel van die oorsig is om die begrip 'algehele welstand' te verduidelik en om die voordele van 'n werkomgewing wat fisieke aktiwiteit toelaat en die nadele van 'n omgewing waarin daar hoofsaaklik gesit word uit te lig wanneer dit op die bereiking van algehele welstand aankom.

The influence of sedentary and active work environments on wellness. The concept of wellness has changed over the decades with the ever-changing lifestyle of society as it adapts to technological advances. The contemporary view is that wellness is the primary responsibility of the individual and is accomplished by practising health-promoting behaviour. There are various factors that contribute to wellness in the sense of an individual's long-term sense of overall well-being. One of the most essential factors is physical activity, and there is a large body of research that explores the benefits of a physically active lifestyle. This article is based on the assumption that the most accurate way to measure these benefits are to compare an active with a sedentary lifestyle. The purpose of this review is to clarify the concept of wellness and highlight the benefits of a physically active working environment as opposed to the disadvantages of a sedentary environment in attaining overall wellbeing.

\section{Inleiding}

Aan die begin van die 20ste eeu was oordraagbare siektes soos griep, polio, witseerkeel en tuberkulose die mees algemene siektes in die Westerse samelewing (Armstrong, Conn \& Pinner 1999). Vordering op mediese gebied het hierdie siektes grootliks uitgeskakel, wat verhoogde lewensgehalte en 'n langer lewe moontlik gemaak het. Dié vooruitgang het egter gepaardgegaan met toenemend sedentêre gedrag, 'n gebrek aan fisieke aktiwiteit en 'n dieet wat al meer vet en minder vesel bevat het. Dit het ook saamgeval met verhoogde vlakke sielkundige stres. Op hul beurt het hierdie veranderinge saamgeloop met ' $n$ toename in die voorkoms van chroniese siektes, met inbegrip van diabetes mellitus tipe 2, kardiovaskulêre siekte, kanker en chroniese respiratoriese siekte. Volgens die Wêreldgesondheidsorganisasie (Hoeger \& Hoeger 2010), is dié nie-oordraagbare siektes tans verantwoordelik vir $60 \%$ van die totale getal sterftes wêreldwyd.

Terwyl die voorkoms van chroniese siektes steeds bly styg het, het dit duidelik geword dat voorkoming die mees doeltreffende metode is om optimale gesondheid te handhaaf. Dit het aanleiding gegee tot die fiksheid- en welsynbeweging, gewortel in die oortuiging dat mense op hulself aangewese is wat die handhawing van gesondheid betref, en dat 'n gesonde lewenstyl daartoe kan bydra om die vernaamste oorsake van voortydige dood teen te werk (Hoeger \& Hoeger 2010). Die strewe van hierdie beweging kan opgesom word deur die opmerking dat die dokters van die toekoms nie medisyne sal voorskryf nie, maar hul pasiënte sal aanmoedig om hul liggaam te versorg, 'n gesonde dieet te volg en om te begryp wat siektes veroorsaak en wat dit kan verhoed. (Nichols 2008:273).

Ofskoon daar ' $n$ oorvloed bewyse is dat ' $n$ aktiewe lewenstyl ' $n$ individu se lewensgehalte baie verbeter, het dit teen die einde van die 20ste eeu duidelik begin blyk dat fisieke aktiwiteit en oefening op sigself nie genoeg is om beter gesondheid en verlaagde risiko van siekte te verseker

Copyright: @ 2013. The Authors. Licensee: AOSIS OpenJournals. This work is licensed under the Creative Commons Attribution License. 
nie (Hoeger \& Hoeger 2009). Die siening dat gesondheid bloot die afwesigheid van siekte is, is lank reeds iets van die verlede en met voortgaande navorsing oor die uitwerking van lewenstylfaktore op welstand, wen die siening steeds veld dat daar ander faktore is wat betrokke is (Hoeger \& Hoeger 2010). Die bereiking van 'n toestand van welstand vereis ' $n$ doelbewuste poging om die hoogste potensiaal vir gesondheid en welstand te bereik en te handhaaf. Dit vereis op sy beurt gedragsverandering deur positiewe lewensgewoontes te handhaaf ten einde gesondheid, lewensgehalte en algehele welstand te verbeter (Hoeger \& Hoeger 2010).

Die toenemende gesondheidskrisis wêreldwyd, weens swak lewenstylkeuses, werk 'n skerper fokus op die bereiking van welstand in die hand. Haby, Markwick en Peeters (2012) voorspel dat as die huidige voorkoms van vetsug gehandhaaf word, 33\% van Australiese kinders tussen die ouderdomme van 5 en 19 teen die jaar 2025 oorgewig of vetsugtig sal wees, asook $83 \%$ van mans en $75 \%$ van vroue wat 20 jaar of ouer is. Die algemene toename in die voorkoms van vetsug wêreldwyd sal 'n aansienlike impak op die globale siektelas hê - met verreikende gevolge. Vroeë bewustheid van die probleem en ingrepe is noodsaaklik om te verseker dat dié voorspelling nie bewaarheid word nie.

Die dramatiese toename in die gewildheid van welstandsentrums (Siefken et al. 2012; Kickbusch \& Payne 2003) het gepaardgegaan met ' $n$ toenemende belangstelling in die welstandsbegrip, veral in die korporatiewe sektor. Die programme wat deur die welstandsentrums aangebied word, kry in die jongste tyd kommersieel goed aftrek en word met ywer en entoesiasme gevolg. In hierdie navorsingsoorsig word daar gepoog om sedentêre en aktiewe werksomgewings te omskryf en om die uitwerking van dié omgewings op die bereiking van algehele welstand te beklemtoon.

\section{Omskrywing van sedentêre en aktiewe werksomgewings}

Daar is minstens twee omskrywings van sedentêre gedrag in die vakliteratuur. Lowry et al. (2002) omskryf dit as onvoldoende fisieke aktiwiteit van matige intensiteit, terwyl Lovelady et al. (2000) dit omskryf as deelname aan oefening nie meer dikwels as een keer per week nie vir die duur van drie maande.

Benewens sedentêre gedrag, is dit nodig om ook fisieke aktiwiteit en oefening duidelik te omskryf. Die American College of Sports Medicine (ACSM) (American College of Sports Medicine 2010) omskryf fisieke aktiwiteit as liggaamlike beweging wat veroorsaak word deur die werking van skeletspiere wat 'n beduidende toename van energieverbruik bo dié van 'n rustende staat veroorsaak. In hul navorsingsoorsig van fisieke aktiwiteit, oefening en fiksheid, klassifiseer Caspersen, Powell en Christenson (1985) oefening as 'n onderverdeling van fisieke aktiwiteit wat 'n gestruktureerde, herhalende program behels met die oog daarop om fiksheidsvlakke te verbeter of te handhaaf. Fiksheid word beskryf as gesondheidsof vaardigheidsverwante eienskappe wat 'n individu in staat stel om daaglikse bedrywighede met ywer en wakkerheid te vermag, terwyl hy steeds in staat is om ontspanningsbedrywighede en onvoorsiene omstandighede te hanteer sonder oormatige moegheid (Caspersen, Powell \& Christenson 1985).

Daar is ' $n$ dosis-responsverhouding tussen fisieke aktiwiteit en oefening enersyds, en gesondheidsuitkomste andersyds, in dié sin dat die gevolge van die handhawing van fisiologiese gesondheid en fiksheid 'n funksie is van die hoeveelheid fisieke aktiwiteit wat gehandhaaf word (Buckley \& Buckley 2008). Vier afsonderlike komponente van fisieke aktiwiteit kan gemeet word: frekwensie, intensiteit, tipe en tyd. Dit staan bekend as die FITT-beginsel (Thow 2006). As die komponente op gepaste wyse verander word, vind fisiologiese veranderinge plaas op sowel die vlak van hele liggaamsdele as op sellulêre vlak, wat lei tot verbeterde fiksheid (Katch 1983). Een manier om te bepaal of fisieke aktiwiteit in die sedentêre of in die aktiewe deel van die spektrum val, is deur intensiteit te meet. Dit word gedoen deur die beoordeling van die metaboliese ekwivalente (MET'e) ten einde die hoeveelheid energie wat in die uitvoering van ' $n$ bepaalde taak verbruik word te kwantifiseer. Dit kan beskryf word as die metaboliese energiebrandingskoers (Evans \& White 2009). Daarom kan die MET-vlak in 'n bepaalde geval beskou word as die algehele vlak van inspanning van iemand wat 'n fisieke taak uitvoer.

Die ACSM en Centres for Disease Control and Prevention (CDC) (American College of Sports Medicine 2010) het fisieke aktiwiteit geklassifiseer volgens die MET'e wat vereis word - lig: minder as 3 MET'e; matig: tussen 3 en $6 \mathrm{MET}^{\prime} \mathrm{e}$, en energiek: meer as $6 \mathrm{MET}^{\prime} \mathrm{e}$.

Verskeie studies plaas sedentêre aktiwiteit in dieselfde kategorie as fisieke lewenstyl- en vryetydsaktiwiteit, wat almal 3 MET'e of minder vereis. In vorige navorsingsoorsigte is fisieke lewenstylaktiwiteit gedefinieer as ten minste 30 minute per dag van fisieke aktiwiteit van matige tot hoë intensiteit volgens die individu se keuse; dit kan óf beplande óf onbeplande ontspannings-, beroeps- of huishoudelike aktiwiteite insluit (Dunn 2009). In die navorsingsoorsig van Dunn (2009) is bevind dat wanneer 'n gestruktureerde oefenprogram vergelyk word met die gegewe vlakke van fisieke lewenstylaktiwiteit, beide 'n verbetering in risikofaktore soos cholesterolprofiel, sistoliese bloeddruk, liggaamlike samestelling en maksimale suurstofverbruik vertoon het. Daar moet egter in gedagte gehou word dat Dunn se primêre fokus was op die beoordeling van watter groep die beste instandhoudingsrekord gehad het.

'n Verwante metode om sedentêre of aktiewe lewenstyl te meet is deur die aërobiese kapasiteit te bepaal ook bekend as $\mathrm{VO}_{2 \max }$. Dit beskryf die volume suurstof wat verbruik word per minuut per kilogram van liggaamsgewig, of eerder die maksimum hoeveelheid suurstof per minuut wat die spiere in staat is om doeltreffend te benut tydens fisieke aktiwiteit (Buckley \& Buckley 2008; Evans \& White 2009). 
Studies het getoon dat die bereiking van $\mathrm{VO}_{2 \max }$-waardes van $35.0 \mathrm{~mL} / \mathrm{kg} / \mathrm{min}$ en $32.5 \mathrm{~mL} / \mathrm{kg} / \mathrm{min}$ vir mans en vroue onderskeidelik deur deel te neem aan fisieke aktiwiteit waarskynlik voldoende is om die risiko van alle oorsake van voortydige mortaliteit te verminder (Hoeger \& Hoeger 2010). Die afname in $\mathrm{VO}_{2 \max }$ met ouderdom is goed gedokumenteer (McArdle, Katch \& Katch 2010). Ondanks bevindings dat $\mathrm{VO}_{2 \max }$ voortgegaan het om tussen $8 \%$ en $15 \%$ per dekade te daal as 'n funksie van ouderdom onder uithouvermoë-atlete wat volgehoue oefening oor 'n tydperk van 20 jaar handhaaf, is die hoofstroombevinding dat individue wat fisiek aktief is, 'n aërobiese kapasiteit handhaaf wat $10 \%$ tot $50 \%$ hoër is as hul sedentêre eweknieë (McArdle, Katch \& Katch 2010).

\section{Verduideliking van die welstandbegrip}

Gesondheid en welstand word dikwels as sinonieme gebruik weens die noue verband wat tussen hulle bestaan en hul interafhanklikheid, aangesien albei berus op die fisiologiese, sielkundige, emosionele, sosiale, geestelike en omgewingsfaktore wat bydra tot 'n persoon se algehele lewensgehalte (Edlin, Golanty \& Brown 2000). Maar Edlin, Golanty en Brown (2000) tref 'n duidelike onderskeid tussen gesondheid en welstand: gesondheid is ' $n$ dinamiese proses wat daaglikse keuses vereis ten einde homeostase te handhaaf, terwyl welstand die besef insluit dat sommige invloede en keuses ongesond is en die vind van gesonde alternatiewe gevolglik.

Ten einde welstand te handhaaf is dit nodig om fisiek aktief te wees, om geen tekens van siekte te toon nie en om vry te wees van die risikofaktore vir siektes wat deur lewenstyl geïnduseer word. Daarom, selfs al toon individue 'n voldoende vlak van fiksheid wanneer dit geassesseer word, sal 'n ongesonde lewenstyl hulle steeds aan die verhoogde risiko blootstel om chroniese siektes op te doen en hul welstand verminder (Hoeger \& Hoeger 2010). Die welstandkontinuum, soos uitgebeeld in Figuur 1, toon die verhouding tussen gesondheid en welstand (Edlin, Golanty \& Brown 2000:4; Hoeger \& Hoeger 2010:14).

Die verband tussen fisieke aktiwiteit, fiksheid en gesondheid berus op 'n komplekse interaksie, soos uitgebeeld in Vanhees et al. (2005) (Figuur 2). Hierdie benadering beklemtoon die gesondheidsverwante komponent van welstand, wat in wese beskryf kan word as die gesteldheid van daardie fisieke en fisiologiese eienskappe wat die risikovlakke bepaal vir die ontwikkeling van siektes of morbiditeit wat verband hou met 'n sedentêre lewenstyl (Vanhees et al. 2005:103). Daarbenewens beklemtoon dié benadering die invloed van oefening op die gesondheidsverwante en vaardigheidsverwante komponente van welstand (Vanhees et al. 2005).

Figuur 2 toon die verhouding aan tussen fisieke aktiwiteit, fiksheid en gesondheid, met ander woorde die faktore wat gesondheid en welstand beïnvloed (Vanhees et al. 2005:103). Die omvang van hierdie invloed kan op drie gebiede aangeslaan word: modifiseerbare, gedeeltelik modifiseerbare

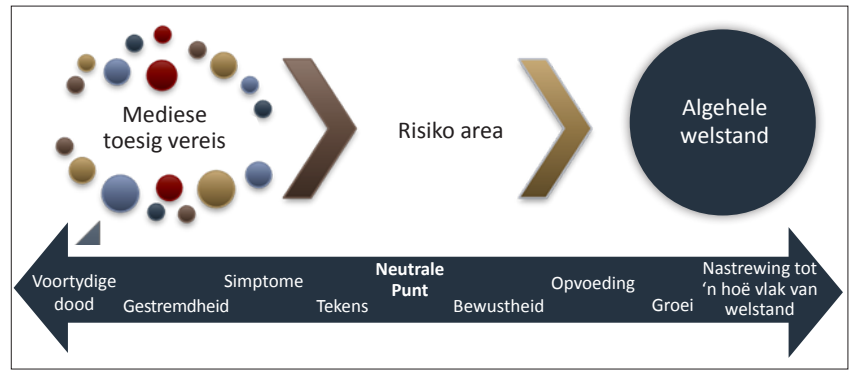

Bron: Gebaseer op Hoeger, W.W.K. \& Hoeger, S.A., 2010, Lifetime physical fitness and wellness: A personalized program, Brooks/Cole, Belmont, TN and Edlin, G., Golanty, E. \& Brown, K.M., 2000, Essentials for health and wellness, Jones \& Bartlett Learning, Burlington, MA

FIGUUR 1: Die welstandskontinuum.

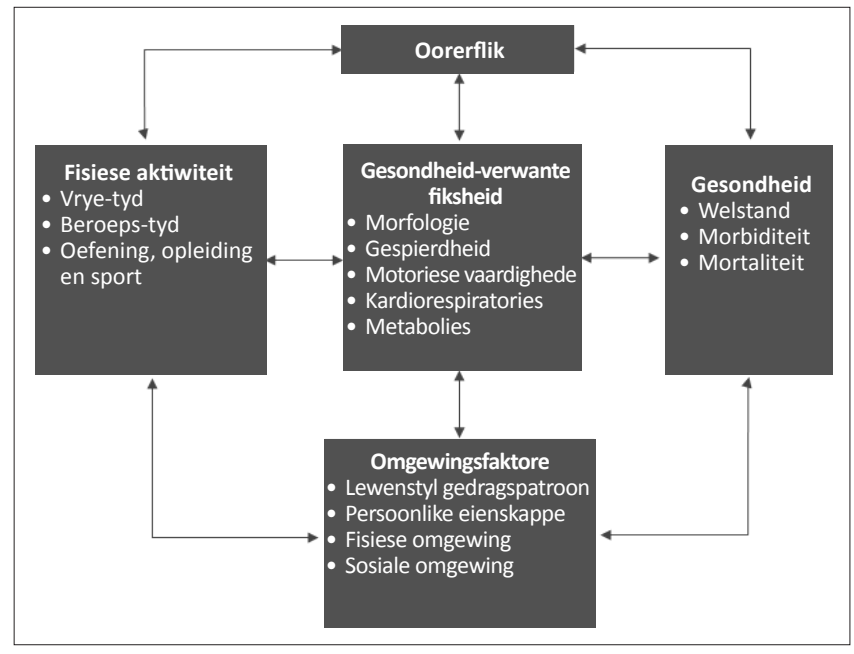

Bron: Gebaseer op Vanhees, L., Lefevre, J., Philippaerts, R., Martens, M., Huygens, W. Troosters, T. \& Beunen, G., 2005, 'How to assess physical activity? How to assess physical fitness', European Journal of Cardiovascular Prevention and Rehabilitation 12(2), 102-114

FIGUUR 2: Faktore wat gesondheid en welstand raak.

en nie-modifiseerbare faktore. Modifiseerbare faktore sluit lewenstyl en gesondheidsorg in. Lewenstyl het die mees beduidende impak op gesondheid en welstand, en daar word dikwels gevind dat dit ook die meeste vatbaarheid toon vir ongunstige veranderinge. Positiewe veranderinge in lewenstyl sluit aanpassings in dieet en oefenroetines in, sowel as wysiging van daaglikse gewoontes, ten einde aan alle vereistes van welstand te voldoen, soos in die vorige afdeling bespreek. Gesondheidsorg sluit in roetinebesoeke aan gesondheidspraktisyne vir assessering, asook empiriese monitering van die gesondheidstatus en enige aanpassings van lewenstyl wat moontlik nodig kan wees. Wat die handhawing van welstand betref, is die fokus op voorkomende gesondheidsorg, in teenstelling met die reaktiewe behandeling van bestaande ongesteldhede. Genetiese faktore word geklassifiseer as niemodifiseerbaar, aangesien 'n persoon, in sommige gevalle, hoogstens kan probeer om die risiko van bepaalde siektes - soos diabetes mellitus tipe 2, hipertensie en aterosklerose - te verminder deur aanpassings aan lewenstyl en gesondheidsorg. Daar is wel tog ook genetiese toestande wat beheer en vertraag kan word ten einde welstand te behou. Omgewingsinvloede word beskou as gedeeltelik modifiseerbaar, aangesien mense die vermoë het om hul omgewing te verander. Die uitgangspunt vir die bereiking van welstand is dus om voort te gaan ongeag eksterne omstandighede. 
Met die toenemende neiging om 'n ongesonde lewenstyl te volg, blyk dit geregverdig om metodes te ondersoek om aspekte van welstand wat aandag verg te identifiseer. Daarom het Ford et al. (2010) tussen 1996 en 2007 'n ondersoek onderneem van meer as 1580220 individue ten einde die tendens in lewenstylfaktore met ' $n$ lae risiko te bepaal. Daar is bevind dat, met verloop van tyd, die persentasie individue wat in hul lewenstyl ál die gewoontes gehad het wat die risiko van chroniese siektes verlaag, van $8.5 \%$ in 1996 tot $7.7 \%$ in 2007 gedaal het. Die faktore wat in die studie gevolg is, was: staking van rook, deelname aan oefening, handhawing van 'n dieet wat die aanbevole hoeveelheid vrugte en groente insluit, asook die handhawing van 'n liggaamsmassa-indeks (BMI) van onder 25.

\section{Voordele van algehele welstand}

Die belangrikheid van fisieke aktiwiteit is reeds in die vroegste studies erken en daarom het die ACSM in 1978 aanbevelings opgestel in 'n poging om fisieke aktiwiteit in die individu se lewenstyl in te sluit (Dubbert 2002). Dit sluit oefeninge in van hoë frekwensie, hoë intensiteit en verlengde duur wat die grootspiergroepe gebruik. Maar, met die veranderende lewenstyl van die algemene bevolking, is die aanbevelings in 1995 hersien en verander na oefeninge van matige intensiteit en verkorte duur, maar met 'n verhoogde frekwensie (Thompson et al. 2009). In daaropvolgende jare is die aanbevelings aangepas ten einde chroniese siektes teen te werk - deur oefeninge in te sluit vir weerstandsopleiding, kardiorespiratoriese en spierfiksheid en om voorsiening te maak vir meer buigsaamheid (Dubbert 2002). Die gewysigde plan het geblyk om baie voordelig te wees, aangesien daar bevind is dat fisieke aktiwiteit en oefening ' $n$ positiewe uitwerking op verskeie siektetoestande het - soos diabetes mellitus tipe 2, kardiovaskulêre siekte, hoë bloeddruk, sekere kankers, osteoporose en emosionele ongesteldhede soos angs en depressie (Dubbert 2002; Penedo \& Dahn 2005; Sothern et al. 1999).

Verskeie studies oor die voordele van fisieke aktiwiteit het 'n positiewe uitwerking geïdentifiseer op die kardiovaskulêre, respiratoriese, endokriene, en muskuloskeletale stelsels. In die besonder is daar gevind dat die fisieke voordele van oefening - soos ' $n$ toename in spierkrag, bewegingsomvang, soepelheid, postuur en uithouvermoë - op húl beurt selfgenoegsaamheid bevorder met 'n gevolglike afname in depressie, afhanklikheid en gebrek aan beheer (Blair, Cheng \& Scott Holder 2001; Dishman et al. 2000; Warburton, Nicol \& Bredin 2006). Gereelde deelname aan fisieke aktiwiteit neig ook om angs te verminder en om die stemming en die vermoë te verbeter van die individu om daaglikse take te verrig. Hierdie voordele is 'n integrerende deel van 'n holistiese gevoel van welstand; dit verminder ook die risiko om verskeie siektes op te doen wat deur lewenstyl geïnduseer word.

In hul navorsing oor middeljarige individue het King, Mainous en Greesey (2007) gevind dat die aanvaarding van gesonde lewensgewoontes soos 'n dieet wat die aanbevole hoeveelhede vrugte en groente insluit, oefening, die handhawing van 'n gesonde gewig en staking van rook sterftes met $40 \%$ en die risiko van kardiovaskulêre siekte met $35 \%$ verminder na 'n tydperk van vier jaar, in vergelyking met minder gesonde lewenstyle. Verder is bevind dat hierdie uitwerking onafhanklik van ouderdom, ras, geslag, pasiëntgeskiedenis en sosiaal-ekonomiese status voorgekom het (King, Mainous III \& Geesey 2007).

Een van die fundamentele voordele van fisieke aktiwiteit is die verminderde risiko van voortydige dood. In die navorsingsoorsig van Warburton, Nicol en Bredin (2006) word gekonstateer dat die verhoging van fisieke aktiwiteit met 1 MET die mortaliteitsrisiko met 20\% verminder. Dubbert (2002) berig 'n omgekeerde dosis-responsverhouding tussen fisieke aktiwiteit en sterftes weens toestande soos koronêre hartsiekte, beroerte en kolonkanker. Daar is ook aansienlike aanduidings van die positiewe uitwerking van fisieke aktiwiteit op toestande soos nie-insulienafhanklike diabetes mellitus, osteoartritis en vetsug (Dubbert 2002). In sommige siektetoestande soos kanker en nie-insulienafhanklike diabetes mellitus, is die presiese onderliggende meganismes egter nog nie vasgestel nie.

Terwyl verskeie studies ten gunste is daarvan om 30 minute van ontspannende aktiwiteit te koppel aan 'n werkdag van agt uur ten einde kardiovaskulêre siekte te bekamp (Warburton, Nicol \& Bredin 2006), meen Shephard (2001) dat dit nie voldoende is nie vanweë die lae intensiteit en stel voor dat ' $n$ intensiteit van ses MET'e vereis word vir kardiovaskulêre voordeel. Ander navorsing dui daarop dat aërobiese aktiwiteit van lig tot matige intensiteit $\left(40 \% \mathrm{VO}_{2 \max }\right.$ $-60 \% \mathrm{VO}_{2 \max }$ ) voldoende is om 'n gesonde lewenstyl in stand te hou (Shephard 2001).

Lewenstylverwante gedrag soos voedingstatus is van kardinale belang by die handhawing van welstand. In hul studie bevind Andersen et al. (1999) dat 'n program wat dieet en oefening kombineer, 'n positiewe uitwerking het op die verligting van toestande wat met vetsug verband hou - oormatige gewig, sistoliese bloeddruk, asook hoë serumlipied- en lipoproteïenvlakke. Die studie het fisieke aktiwiteit wat deel van die lewenstyl is met'n gestruktureerde oefenprogram vergelyk en bevind dat die handhawing van 'n gesonde dieet voordele inhou ongeag die aard van die oefening.

\section{Gevolge van sedentêre gedrag}

Evolusionêre biologie dui daarop dat die menslike genoom sy basiese struktuur behou het sedert die LaatPaleoliticum toe mense as jagter-versamelaars oorleef het (Booth, Chakravarthy \& Spangenburg 2002). Dit was 'n oorlewingskultuur wat noodwendig moes staatmaak op voortdurende fisieke aktiwiteit en die uitdrukking van gene is geselekteer om hierdie lewenstyl te akkommodeer. Maar as gevolg van tegnologiese vooruitgang is die moderne mens geplaas in 'n omgewing wat sedentêre gedrag verg.

Ofskoon die genotipe van die hedendaagse Homo sapiens in treffende mate soortgelyk is aan dié van ons Laat-Paleolitiese 
voorvaders, verskil die fenotipiese uitdrukking van gene. Daar word bespiegel dat die rede hiervoor is dat die evolusionêr geprogrammeerde Laat-Paleolitiese gene in die moderne era uitgedruk word in 'n omgewing wat grootliks sedentêr is (Booth, Chakravarthy \& Spangenburg 2002). Dit lei tot' $n$ wanaanpassing van die genoom van die hedendaagse Homo sapiens, wat weer abnormale geenuitdrukking tot gevolg het en uiteindelik die voorkoms van, waarna verwys word as, lewenstylverwante siektes. Booth, Chakravathy en Spangenburg (2002) spekuleer dat hierdie gene gedeeltelik verantwoordelik is vir die daling in oorlewingsyfers, ofte wel wat beskou kan word as voortydige dood te wyte aan nie-oordraagbare siektes weens 'n onaktiewe lewenstyl. Dit word verder deur Gerber en Crews bevestig, soos aangehaal in Booth, Chakravathy en Spangenburg (2002), wat beweer dat, weens die blootstelling van allele aan 'n sedentêre lewenstyl, sowel as diëte wat ryk is aan vet en suiker, maar 'n tekort het aan vesel, loop draers die risiko van chroniese degeneratiewe siektes en verlaagde lewensverwagting.

Dit word algemeen aangevoer dat ontwrigting in homeostatiese meganismes merkbaar teëgewerk word in aktiewe individue in teenstelling met sedentêre individue. Darwin se teorie van natuurlike seleksie onderskryf hierdie standpunt in die sin dat die natuurlike seleksie van geenuitdrukking die fisiek aktiewe lewenstyl van jagterversamelaars verkies. Dit volg derhalwe dat gene ontwikkel het met die 'verwagting' van'n aktiewe lewenstyl om normale fisiologiese geenuitdrukking te verseker, en dat oefening om 'n aktiewe lewenstyl te handhaaf dus die versteurde homeostatiese meganismes sal herstel en nader bring aan die fisiologiese omstandighede van die jagter-versamelaars.

Die model in Figuur 3 voorsien 'n raamwerk vir die vertolking van die gevolge van sedentêre gedrag (Booth, Chakravarthy \& Spangenburg 2002:401). Die uitgangspunt van hierdie model is dat gebrek aan fisieke aktiwiteit homeostase ontwrig deur die afregulering van gene wat fisieke aktiwiteit vereis. Dit lei tot essensiële proteïen-inhibering en die gevolglike aktivering van proteïene wat siekte bevorder, proteïene wat deur 'n kaskade van intrasellulêre reaksies manifesteer in nie-oordraagbare siektetoestande wat uiteindelik lei tot 'n afname in lewensverwagting.

Dit is duidelik dat die risiko's wat verband hou met ' $n$ gebrek aan fisieke aktiwiteit swaarder weeg as die voordele van fisieke aktiwiteit. Fisieke onaktiwiteit dra by tot 'n verhoogde risiko van verskeie siektes soos kardiovaskulêre siekte, hemorragiese beroerte, verlaagde glukosetoleransie en insuliensensitiwiteit weens verhoogde abdominale adipositeit, hoë bloeddruk en hipercholesterolemie (Warburton, Nicol \& Bredin 2006; Shephard 2001; Rennie et al. 2003). Die Wêreldgesondheidsorganisasie (Siefken et al. 2012) erken fisieke onaktiwiteit as 'n globale gesondheidsprobleem en het dit vierde geplaas op die ranglys van algehele mortaliteitslas wat aan risikofaktore toegeskryf kan word, wat verantwoordelik is vir $6 \%$ van sterftes wêreldwyd.

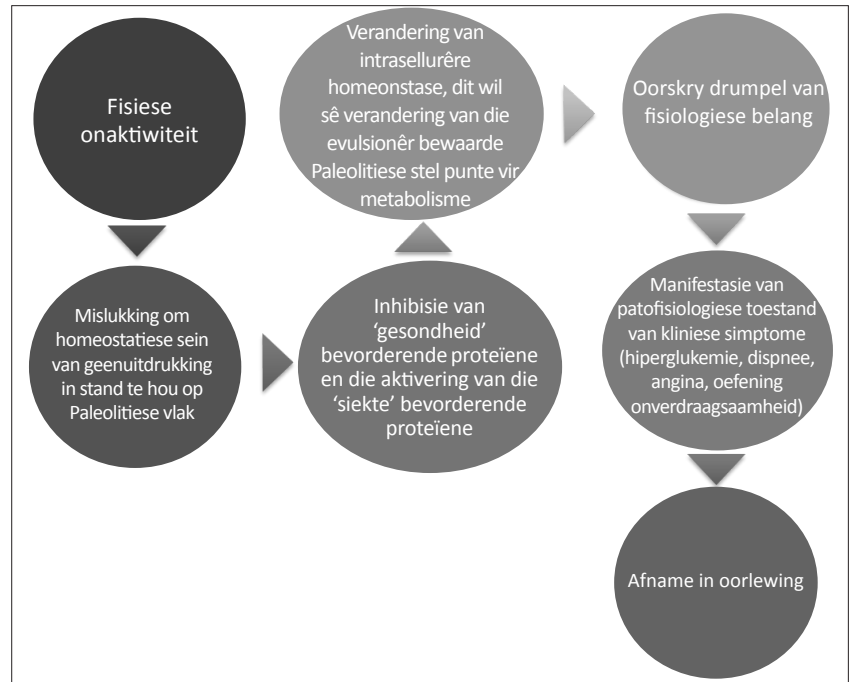

Bron: Gebaseer op Booth, F.W., Chakravarthy, M.V. \& Spangenburg, E.E., 2002, 'Exercise and gene expression: Physiological regulation of the human genome through physical activity', Journal of Physiology 543(2), 399-411

FIGUUR 3: Die invloed van lewenstylfaktore op genetiese vatbaarheid, wat lei tot 'n kaskade van gevolge wat uiteindelik chroniese toestande in die hand werk en oorlewingsyfers verlaag.

Om volhoubare welstand te verseker is die menslike liggaam afhanklik van beweging en fisieke aktiwiteit. Bevindinge toon dat fisieke onaktiwiteit ernstige gevolge vir gesondheid kan inhou en die tempo van die agteruitgang van die menslike liggaam bespoedig. In hierdie tegnologiese era is daar feitlik geen noodsaaklikheid meer vir fisieke aktiwiteit nie, veral in die werksomgewing. Die meeste geïndustrialiseerde lande ondervind 'n epidemie van fisieke onaktiwiteit, wat in die verhoogde voorkoms van lewenstylverwante chroniese toestande waargeneem word. Daar is bevind dat Sedentêre Sterftesindroom, ' $n$ term wat geskep is om die oorsaak van sterftes te beskryf wat toegeskryf word aan 'n gebrek aan gereelde fisieke aktiwiteit, die tweede grootste bedreiging vir gesondheid in die VSA is (Hoeger \& Hoeger 2010).

\section{Gevolgtrekking}

Die gevolge van sedentêre gedrag belemmer ' $n$ individu se vermoë om 'n gevoel van fisieke welstand te bereik en gevolglik word algehele welstand verhinder. Dus, ten einde werklike algehele welstand te bereik, is dit noodsaaklik om 'n aktiewe lewenstyl te handhaaf. Dié oorsig het getoon dat fisieke aktiwiteit nie alleen groot voordele vir algemene gesondheid inhou nie, maar ook allerbelangrik is by die voorkoming van die meeste nie-oordraagbare siektes.

\section{Erkenning Outeursbydrae}

Die aard van die bydraes van elke outeur, kan kortliks min of meer as volg opgesom word: P.d.T. (Universiteit van Pretoria) was die projekleier; L.A.N. (Universiteit van Pretoria) was verantwoordelik vir die samestelling van oorspronklike manuskrip; E.N. (Universiteit van Pretoria) vir die redigering en finale voorbereiding van die manuskrip; M.K. (Universiteit van Pretoria) vir die statistiese analise. L.A.N., P.d.T., E.N. en M.K. was betrokke by die projekontwerp, 
dataversameling en uitvoering van die toetsprosedures, waar R.F. (Universiteit van Pretoria) en G.G. (Universiteit van Pretoria) het konseptuele bydraes gelewer.

\section{Mededingende belange}

Die outeurs verklaar hiermee dat hulle geen finansiële of persoonlike verbintenis het met enige party wat hulle nadelig of voordelig kon beïnvloed het in die skryf van hierdie artikel nie.

\section{Literatuurverwysings}

American College of Sports Medicine, 2010, American College of Sports medicine's guidelines for exercise testing and prescription, Wolters Kluwer Health/Lippincott guidelines for exercise testing and pres
Williams \& Wilkins, Baltimore, MD.

Andersen, R.E., Wadden, T.A., Bartlett, S.J., Zemel, B., Verde, T.J. \& Franckowiak, S.C., 1999, 'Effects of lifestyle activity vs structured aerobic exercise in obese women: A randomized trial', Journal of the American Medical Association 281(4), 335-340. $\mathrm{http}: / / \mathrm{dx}$.doi.org/10.1001/jama.281.4.335, PMid:9929086

Armstrong, G.L., Conn, L.A. \& Pinner, R.W., 1999, 'Trends in infectious disease mortality in the United States during the 20th century', Journal of the American Medical Association 281(1), 61-66. http://dx.doi.org/10.1001/jama.281.1.61, PMid:9892452

Blair, S.N., Cheng, Y. \& Scott Holder, J., 2001, 'Is physical activity or physical fitness more important in defining health benefits?', Medicine and science in sports and exercise 33(6), S379-S399. http://dx.doi.org/10.1097/00005768-20010600100007, PMid:11427763

Booth, F.W., Chakravarthy, M.V. \& Spangenburg, E.E., 2002, 'Exercise and gene expression: Physiological regulation of the human genome through physica activity', Journal of Physiology 543(2), 399-411. http://dx.doi.org/10.1113/ jphysiol.2002.019265, PMid:12205177, PMCid:PMC2290514

Buckley, J.P. \& Buckley, J., 2008, Exercise physiology in special populations: Advances in Sport and Exercise Science, Elsevier Science Health Science Division, Philadelphia, PA.

Caspersen, C.J., Powell, K.E. \& Christenson, G.M., 1985, 'Physical activity, exercise, and physical fitness: Definitions and distinctions for health-related research', Public Health Reports (1974-) 100(2), 126-131.

Dishman, R.K., Nakamura, Y., Garcia, M.E., Thompson, R.W., Dunn, A.L. \& Blair, S.N., 2000, 'Heart rate variability, trait anxiety, and perceived stress among physically fit men and women', International Journal of Psychophysiology 37(2), 121-133. http://dx.doi.org/10.1016/S0167-8760(00)00085-4

Dubbert, P.M., 2002, 'Physical activity and exercise: Recent advances and current challenges', Journal of consulting and clinical psychology 70(3), 526-536. http:// dx.doi.org/10.1037/0022-006X.70.3.526, PMid:12090367

Dunn, A.L., 2009, 'Effectiveness of lifestyle physical activity interventions to reduce cardiovascular disease', American Journal of Lifestyle Medicine 3(1) 11S-18S. http://dx.doi.org/10.1177/1559827609336067, PMid:20161356, PMCid:PMC2777660

Edlin, G., Golanty, E. \& Brown, K.M., 2000, Essentials for health and wellness, Jones \& Bartlett Learning, Burlington, MA. PMCid:PMC1070710

Evans, C.H. \& White, R.D., 2009, Exercise testing for primary care and sports medicine physicians, Springer, New York, NY. http://dx.doi.org/10.1007/978-0-387-76597-6

Ford, E.S., Li, C., Zhao, G., Pearson, W.S., Tsai, J. \& Greenlund, K.J., 2010, 'Trends in low-risk lifestyle factors among adults in the United States: Findings from the Behavioral Risk Factor Surveillance System 1996-2007', Preventative Medicine 51(5), 403-407. http://dx.doi.org/10.1016/j.ypmed.2010.08.002, PMid:20708637
Haby, M.M., Markwick, A., Peeters, A., Shaw, J. \& Vos, T. 2012, Future predictions of body mass index and overweight prevalence in Australia, 2005 - 2025, Health Promotion International 27(2), 250-260. http://dx.doi.org/10.1093/heapro/ Promotion Internationa

Hoeger, W.W.K. \& Hoeger, S.A., 2010, Lifetime physical fitness and wellness: A personalized program, Brooks/Cole, Belmont, TN.

Hoeger, W.W.K. \& Hoeger, S.A., 2009, Principles and labs for fitness and wellness, Brooks/Cole, Belmont, TN. PMCid:PMC3756311

Katch, V.L., 1983, 'Physical conditioning of children', Journal of Adolescent Health Care 3(4), 241-246. http://dx.doi.org/10.1016/S0197-0070(83)80245-9

Kickbusch, I. \& Payne, L., 2003, 'Twenty-first century health promotion: The public health revolution meets the wellness revolution', Health promotion internationa 18(4), 275-278. http://dx.doi.org/10.1093/heapro/dag418, PMid:14695358

King, D.E., Mainous III, A.G. \& Geesey, M.E., 2007, 'Turning back the clock: Adopting a healthy lifestyle in middle age', American Journal of Medicine 120(7), 598-603. http://dx.doi.org/10.1016/j.amjmed.2006.09.020, PMid:17602933

Lovelady, C.A., Garner, K.E., Moreno, K.L. \& Williams, J.P., 2000, 'The effect of weight loss in overweight, lactating women on the growth of their infants', New England Journal of Medicine 342(7), 449-453. http://dx.doi.org/10.1056/ NEJM200002173420701, PMid:10675424

Lowry, R., Wechsler, H., Galuska, D.A., Fulton, J.E. \& Kann, L., 2002, 'Television viewing and its associations with overweight, sedentary lifestyle, and insufficient consumption of fruits and vegetables among US high school students: Differences by race, ethnicity, and gender', Journal of School Health 72(10), 413-421. http:// dx.doi.org/10.1111/j.1746-1561.2002.tb03551.x, PMid:12617028

McArdle, W.D., Katch, F.I. \& Katch, V.L., 2010, Exercise physiology: Nutrition, energy, and human performance, Wolters Kluwer Health/Lippincott Williams \& Wilkins, Philadelphia, PN.

Nichols, J.H., 2008, 'The future of point-of-care testing', Point of Care 7(4), 271-273.

Penedo, F.J. \& Dahn, J.R., 2005, 'Exercise and well-being: A review of mental and physical health benefits associated with physical activity', Current Opinion in Psychiatry 18(2), 189-193. http://dx.doi.org/10.1097/00001504-20050300000013, PMid:16639173

Rennie, K.L., Hemingway, H., Kumari, M., Brunner, E., Malik, M. \& Marmot, M., 2003, 'Effects of moderate and vigorous physical activity on heart rate variability in a British study of civil servants', American Journal of Epidemiology 158(2), 135-143. http://dx.doi.org/10.1093/aje/kwg120, PMid:12851226

Shephard, R.J., 2001, 'Absolute versus relative intensity of physical activity in a doseresponse context', Medicine and science in sports and exercise 33(6), S400 -\$418. $\mathrm{http}: / / \mathrm{dx}$.doi.org/10.1097/00005768-200106001-00008, PMid:11427764

Siefken, K., Macniven, R., Schofield, G., Bauman, A. \& Waqanivalu, T., 2012, 'A stocktake of physical activity programs in the Pacific Islands', Health promotion international 27(2), 197-207. http://dx.doi.org/10.1093/heapro/dar026, PMid:21561985

Sothern, M.S., Loftin, M., Suskind, R.M., Udall, J.N. \& Blecker, U., 1999, 'The health benefits of physical activity in children and adolescents: Implications for chronic disease prevention', European journal of pediatrics 158(4), 271. http://dx.doi. disease prevention, European journal of pediat
org/10.1007/s004310051070, PMid:10206121

Thompson, W.R., Gordon, N.F. \& Pescatello, L.S., 2009, ACSM's guidelines for exercise testing and prescription, Lippincott Williams \& Wilkins, Baltimore, MD.

Thow, M., 2006, Exercise leadership in cardiac rehabilitation: An evidence-based approach, John Wiley \& Sons, Chichester. PMid:16824299

Vanhees, L., Lefevre, J., Philippaerts, R., Martens, M., Huygens, W., Troosters, T. \& Beunen, G., 2005, 'How to assess physical activity? How to assess physical fitness', European Journal of Cardiovascular Prevention and Rehabilitation 12(2), 102-114. http://dx.doi.org/10.1097/01.hjr.0000161551.73095.9c, PMid:15785295

Warburton, D.E.R., Nicol, C.W. \& Bredin, S.S.D., 2006, 'Health benefits of physical activity: The evidence', Canadian Medical Association Journal 174(6), 801-809. http://dx.doi.org/10.1503/cmaj.051351, PMid:16534088, PMCid:PMC1402378 